\title{
Changes in the verb phrase in legislative language in English ${ }^{1}$
}

\author{
Christopher Williams \\ University of Foggia
}

\section{Introduction: defining our terms of reference}

It is a well-known fact that the language of the law, together with the language of religion, tends to be more resistant to change than practically any other genre. Darmstadter (2008: 229) observes that law "is both relentlessly formal and relentlessly conservative". The hidebound nature of the language of lawyers is partly attributable to "the conservatism of the profession and its veneration of history and tradition" (Tiersma 2011). Mattila (2006: 98) hypothesises that legal language is "perhaps the oldest of all languages for special purposes". He also points out that "we should bring to mind the specifics of the notion of style in the Middle Ages, and the fact that notions of style are deeply ingrained" (ibid.).

We must make an initial distinction between legal language and the language of the law (Maley 1994: 12-13; Trosborg 1995: 32; Williams 2005: 23-25). The former is generally used when referring to any type of communication coming within the legal sphere, either written or oral, and includes courtroom discourse, law reports, academic texts on legal matters, communication between lawyer and client or between lawyers, as well as legally binding texts. The latter conventionally refers only to prescriptive texts such as laws, treaties, regulations, contracts or wills. These are generally written, though they may sometimes be oral, as when a judge pronounces a verdict in court. But even in such cases as these the judge is often reading aloud from a written script.

Some of the subgenres within legal language - such as the language of jury trial - involve interaction between legal experts and members of the general public. Heffer (2005: 35) defines this type of verbal communication, produced by legal professionals and received by lay participants, as "legal-lay discourse". However, my analysis will be restricted to the language of legal documents i.e. prescriptive texts written by drafters and aimed at a readership essentially made up of legal experts - a subgenre considered to be "about as far removed as possible from informal spontaneous conversation" (Crystal and Davy 1969: 194).

The language of legal documents itself constitutes a vast area which can be loosely subdivided into two distinct types of text: documents that are drafted by legislative bodies, which may range from international treaties to local council regulations, and documents that are drafted to regulate private relationships, e.g. business or insurance contracts, contracts of employment, contracts of sale, and wills. Generally speaking, the former type has tended to be more open to change than the latter in recent decades (Williams 2010).

In this paper I will focus on documents drafted by legislative bodies. In investigating the changes that have taken place in the verb phrase in legislative English in recent decades, my analysis will add another dimension to the concept of 'current change' with respect to the other chapters in this volume, insofar as changes occurring in legislative language may be the result of prescriptive engineering rather than of subconscious choice. Over the last few decades, several parliamentary counsels and drafting bodies have responded to the request to modernise legal English in general, leading in some cases to what has been defined as a "modal revolution" (Williams 2009), with regard to the choice of modal auxiliaries. As a result, a number of drafting style manuals have been updated over the last two or three decades in line with the calls for change, and drafters have generally complied with the new guidelines. My aim, then, is to illustrate to what extent transformations have taken place in the verb phrase in legislative language in different parts of the English-speaking world.

\footnotetext{
${ }^{1}$ An early version of this paper was presented at the symposium Current Change in the English Verb Phrase held at University College London in July 2009. I am grateful to Bas Aarts, Jo Close, Gunther Kaltenböck, Geoffrey Leech, Sean Wallis and an anonymous reader for their comments and suggestions.
} 
It should be borne in mind that the language of the law has a low frequency of finite verbal constructions. According to one survey (Williams 2005: 97), there is an average of one finite verbal construction for every 20.2 words in legislative texts in English. Legal documents tend to be 'nouny' rather than 'verby': for example, definition provisions often contain long lists consisting of noun phrases, as in (1).

(1) "electricity-supply emissions" in relation to emissions of a targeted greenhouse gas, means any such emissions (wherever their source) that are wholly or partly attributable to, or to commercial activities connected with, the generation, transmission, distribution or supply of electricity or the provision or use of electricity interconnectors. ${ }^{2}$

This 'nouny' aspect of legal documents (Cutts 2001: 9; Woolever 2006) is further emphasised by the high degree of nominalisation that tends to characterise formal discourse in general (Charrow and Charrow 1979: 1321; Vázquez 2006). In legal English nominalisation may sometimes be used, like the passive, in order to "depersonalize" (Tiersma 1999: 77) a statement, while it may also help drafters to make provisions "more compact and yet precise and all-inclusive" (Bhatia 1994: 142).

In order to provide a variety of perspectives in relation to recent changes in the verb phrase in English in legislative language, I have chosen to focus in particular on the United Kingdom and Australia out of the various English-speaking countries, but I also take into consideration texts produced by the European Union, where English is one of the 23 languages officially recognised as being 'authentic', i.e. as having legal force.

\section{Historical background}

As a colonial power, the British imposed not only their language, but also their legal system on the territories they invaded and ruled over. Even today, English is still adopted as an official language in the higher courts in former colonies such as Nigeria, Tanzania, Hong Kong, India and Pakistan.

The common law system continues to be operative today in English-speaking countries such as Australia and New Zealand. It is still the predominant legal system to be found in the United States and Canada, though the latter has also absorbed elements of the civil law system as a result of French influence. Unlike the civil law system which operates in most continental European countries and is based on codified law, common law has traditionally been governed by precedent, which means that judges must take into account the rulings of previous judicial cases. Moreover, in the common law system judges are required to interpret texts narrowly and literally. The consequence of this rationale is that if a particular phrase or expression has been deemed acceptable by judges in the past there is little incentive to change it. This has led to the conservation of a number of archaic terms and expressions. These features of 'legalese' - e.g. the inclusion of strings ${ }^{3}$ such as null and void, or give, devise and bequeath, an antiquated phraseology (e.g. in witness whereof, hereinafter, whereas), the profusion of syntactic discontinuities (Bhatia 1993: 112), and lexical repetition - tend to abound above all in business contracts, making them appear cluttered and a chore to read (Adams 2008; Williams 2010).

Almost half a century has passed since Mellinkoff published The Language of the Law (1963), a penetrating critique of legalese which helped to launch the movement for clarity in legal writing. His premise was that "the law thrived on gobbledygook". 4

\footnotetext{
${ }^{2}$ Section 17(7) of the UK Energy Act 2010.

3 The word 'strings' (Adams 2008: 363) may be preferable to the more commonly used 'binomial expressions' (e.g. Bhatia 1993) on two counts: firstly because it allows us to include expressions of more than two synonyms (or nearsynonyms), and secondly because it could be objected that the word 'binomial' refers only to nouns, whereas it is possible to find strings of synonymous (or near-synonymous) adjectives, adverbs, verbs, or even prepositions in legal English.

${ }^{4}$ www.law.ucla.edu/home/index.asp?page=835 (last accessed 9 February 2010).
} 
It was during the 1970s that what is now generally referred to as the plain language (or plain English) movement - in actual fact a loose group of grassroots organisations rather than a coordinated 'movement' - began to impact on legal language, first in the United States, and then spreading to the UK and other English-speaking countries. By the end of the 1970s the first of a series of manuals endorsing the principles of plain English in legal language had been published (Wydick 1979).

It was in the spheres of banking and insurance that the influence of plain language principles was first felt, whereas most legal drafting establishments were initially sceptical about the need to modernise their drafting style. But in the late 1980s and early 1990s the Offices of Parliamentary Counsel of Australia and New Zealand heeded the call and began to endorse innovative changes in the way laws were drafted. Since then it would be true to say that, in the English-speaking world as a whole, there has been a greater willingness to modernise legal texts on the part of legislative drafters than there has been by lawyers drafting texts regulating private legal relationships. There are, of course, notable exceptions - on both sides - to this generalisation. Some companies take pride in their endorsement of plain language. And the legal establishments of the United States and of the United Kingdom had both tended to be relatively impervious to calls for change until recently (Williams 2007).

\section{A case of prescriptive engineering?}

Given that not only the Offices of Parliamentary Counsel of various English-speaking countries, such as those of Australia (Australia Office of Parliamentary Counsel 2003), New Zealand (New Zealand Parliamentary Counsel Office 2009) or Scotland (Office of the Scottish Parliamentary Counsel 2006), but also the legislative drafting offices of international bodies such as the European Union (European Parliament, the Council and the Commission 2003; European Commission Directorate-General for Translation 2010) have published legal drafting manuals providing guidance to drafters, and given the ubiquity of plain language organisations in the English-speaking world, it is arguable that any changes that have taken place in English legislative discourse over the last few decades have been to a large extent the result of prescriptive engineering rather than the outcome of drafters' subconscious choices. Insofar as this may be true, it in no way invalidates the findings of our analysis, for even if some (or arguably most) of the changes may have occurred as a result of nurture rather than nature, they are nonetheless real and quantifiable and hence of interest to linguists. What it does mean, however, is that when we start examining in detail the impact of such prescriptive engineering on the choice of verb phrases in the language of legal documents in individual countries or international institutions, we will come across cases where, for example, at a given moment in history certain modal auxiliaries cease to be used altogether while others may suddenly take on a new lease of life. Some situations will be characterised by abrupt change at a given moment in time, whereas others may show virtually no change at all. The data on which these results are based are outlined in Section 5. Detailed examples are provided in Section 6.

\section{The temporal framework of legally binding documents}

Legally binding documents such as laws, directives, contracts or wills are generally written with the aim of regulating existing situations for the present and the future (Williams 2005: 84-91). They refer not so much to the real world but to a hypothetical world (MacCormick 1978: 104). The consequence of this fact on the verb phrase can be eloquently summarised if we compare the ten most frequently occurring words in a corpus of general English with a corpus made up of contracts: in the former we find is and was occurring respectively in $8^{\text {th }}$ and $9^{\text {th }}$ position, whereas in the latter we find shall and be occurring respectively in $9^{\text {th }}$ and $10^{\text {th }}$ position (Coulthard and Johnson 2007: 40). This indicates not only the centrality of deontic modality but it also points to the widespread 
use of the passive in the language of the law (though we should bear in mind that shall be also occurs frequently in legal discourse as a copula).

Compared with most other genres, the language of the law contains relatively few references to the past, whether it be the recent or the distant past. And of these comparatively rare occurrences of simple past, present perfect and pluperfect tenses, many refer to hypothetical situations, e.g.:

(2) Subsection (2) applies if, before the commencement date, the governing body of a maintained school in England make an application to the Secretary of State which, if it had been made on or after that date, would have been an application under section $3 .^{5}$

For centuries two modal auxiliaries predominated in main clauses in English legislative texts: shall and may. Gotti (2001: 90-91) calculates that on the basis of the statutes written between 1640 and 1710 contained in the Helsinki Corpus shall constituted 81 per cent of all occurrences of central modal verbs, followed at a great distance by may (13 per cent). As we will see shortly, the distribution of modal auxiliaries in prescriptive texts today is more variegated, and in some cases radically different from the past.

Clearly, within the space of an article it is not possible to discuss all the modals, semimodals, and indicative tenses. I will therefore focus primarily on one modal auxiliary that has dominated legal English for so long and which has been the object of such harsh criticism in recent decades, namely shall. But precisely because, as we will see, the frequency of shall in legislative texts in recent decades has either been drastically reduced, or indeed in some cases shall has been completely eliminated from legislative texts, it will be necessary to say a few words about other verbs or verbal constructions which may have been used to replace shall, particularly must, the be to construction, and the present simple.

\section{The data}

It has been claimed that "legal discourse is so conservative in its construction, interpretation and use that it often does not require a large corpus to determine its linguistic frequencies" (Bhatia, Langton and Lung 2004: 207). Even if my aim is to show the extent of changes that have taken place in the verb phrase in legislative English in recent decades, it still holds true that the underlying framework of legislative discourse itself has changed relatively little, despite the (misguided) claims made not long ago by certain drafters that "We use colloquial English wherever we can" (see Williams 2007: 104).

I will be basing my observations in Section 6 on a series of relatively small corpora rather than on one large corpus. My reasons for doing so are twofold. Firstly, I wish to compare the extent to which changes in the verb phrase have occurred in legislative discourse not only in two different parts of the English-speaking world but also in a major international institution such as the European Union, where English is one of the official languages. It is precisely by comparing various situations that significant - albeit sometimes contradictory - patterns emerge. Secondly, in order to be able to provide a relatively exhaustive picture concerning the use and frequency of verbal constructions in legislative texts, the only way to identify all instances of, say, the present simple, is to go through each text manually, a time-consuming activity.

I have compiled three corpora specially for this paper. The first corpus, totalling 500,000 words, ${ }^{6}$ consists of national legislative texts drafted in the United Kingdom between 1970 and 2010. All the Acts were taken from the legislation.gov.uk website from the category 'UK Public General Acts' and were all 'Original (As enacted)', i.e. they did not include subsequent amendments.

\footnotetext{
${ }^{5}$ Section 16(1) of the UK Academies Act 2010.

${ }^{6}$ For ease of comparison, the word count of all the files comprising each of the three specially compiled corpora was rounded off to exactly 20,000 or 100,000 words, simply by cutting off part of the last text in each file so as to ensure that the exact number of words was reached.
} 
Schedules (i.e. lists or inventories added at the end of some laws but which do not form part of the legal provisions per se) and Acts including in their title the word 'Amendment' were not taken into consideration in this or in any other corpus. The corpus was divided into five subcorpora, each consisting of 100,000 words, comprising texts from, respectively, 1970, 1980, 1990, 2000 and 2010. The second corpus, totalling 100,000 words, consists of national legislative texts drafted by the Australian Office of Parliamentary Counsel between 1973 (the comlaw.gov.au website's database only goes back as far as 1973) and 2010. All Acts were taken from the category 'Acts As Made', so as to exclude subsequent amendments to the texts. The corpus was divided into five subcorpora, each consisting of 20,000 words, comprising texts from, respectively, 1973, 1980, 1990, 2000 and 2010.

Within the two corpora described above I have focused in particular on the distribution of prescriptive verbal constructions occurring in legislative texts published in the UK and in Australia in 1980 and in 2010 in order to illustrate the striking changes that have taken place over a 30-year period in both countries. Each of the four subcorpora consists of 20,000 words.

The third corpus, totalling 100,000 words, consists of legally binding texts drafted in their English versions in the European Union between 1973 (the year the United Kingdom and the Republic of Ireland entered the European Community) and 2010. All the texts were taken from the eur-lex.europa.eu/en/index.htm website from the category 'Legislation in force' but excluding Recommendations, Opinions and Resolutions. This corpus too was divided into five subcorpora, each consisting of 20,000 words, comprising texts from, respectively, 1973, 1980, 1990, 2000 and 2010.

I also refer briefly to the law-related corpus taken from Seoane and Williams (2006) which consists of six small subcorpora - each of approximately 20,000 words - made up of English legislative texts from the European Union, New South Wales and the United States. The first three sets of texts were drafted between 1970 and 1976, the last three between 2003 and 2005. The aim was to verify and compare changes occurring in the drafting style over the space of three decades, with particular reference to the frequency of shall and the use of the passive.

The vast majority of the citations in Section 6 are taken from the corpora listed above, but occasionally examples are taken from other sources in order to highlight particular points, in which case the source is specified.

\section{The controversy surrounding shall and the search for alternatives}

We can now begin our survey which centres around the most ubiquitous and controversial of the modal auxiliaries in the history of legal English. Shall has featured heavily in prescriptive texts for centuries because it has long been characterised as conveying obligation or authorisation in the second and third person singular and plural (practically all legislative texts are written exclusively in the third person), ${ }^{7}$ thus differentiating it from the first person singular and plural where, at least in the affirmative form, it tends to express 'pure' future, with little to distinguish it from will (as is well known, in the interrogative form shall often conveys modal rather than temporal meaning). Drafters have traditionally tended to use shall to convey a variety of meanings, from strong obligation (or prohibition if combined with a negative particle) to 'declarations' which have no obligative force as such, as in the case of definition provisions.

\footnotetext{
7 The only exceptions to this are the use of the first person plural in certain constitutional preambles ('We the people...') such as those of the USA, Ireland and South Africa, or the use of the second person in certain local council regulations which are often displayed in public places such as car parks ('You must display a valid parking ticket purchased from the ticket machines if you are parking in a blue marked bay': see Borough of Oadby and Wigston Car Park Rules at www.oadby-wigston.gov.uk/Home/Client\%20Services/Car\%20Parks/Car_Park_Rules.aspx (last accessed 18 May 2010). Wills and certain types of contract such as contracts of employment tend to make use of the first person singular.
} 
(3) ... that provision thereof shall cease to have effect on the remarriage of the party in whose favour it was made, except in relation to any arrears due under it on the date of such remarriage and shall not be capable of being revived. ${ }^{8}$

(4) ... "surrender to custody" shall mean surrendering himself into custody in accordance with subsection (3) of this section. ${ }^{9}$

Indeed, one of the reasons why shall has been so heavily criticised in recent decades is because it has sometimes been used in subordinate clauses in cases where there is clearly no obligative or authoritative force at all and where the present simple would seem to be more suitable. Such occurrences were particularly frequent in the past (see the numerous cases cited in Gotti 2001). It is still possible to come across a few such instances today in US legislation, as in the following citation where the subordinate clause in question has been italicised.

(5) Any provision of this Act held to be invalid or unenforceable by its terms, or as applied to any person or circumstance, shall be construed so as to give it the maximum effect permitted by law, unless such holding shall be one of utter invalidity or unenforceability, in which event such provision shall be deemed severable from this Act and shall not affect the remainder thereof or the application of such provision to other persons not similarly situated or to other, dissimilar circumstances. ${ }^{10}$

However, in the corpora specially compiled for this paper there were no such instances of shall being adopted merely to give a legalistic 'flavour' to the text (Bowers 1989: 294; Foley 2001: 187).

The other major objections to shall are that i) it is rapidly becoming obsolete in everyday speech in several parts of the English-speaking world, notably the United States, thus making it sound antiquated to many people, and ii) precisely because it has been used so ubiquitously in legal texts for centuries, shall has accumulated several different meanings which, it is claimed, makes it ambiguous. ${ }^{11}$

Since the 1980s onwards there has been a concerted campaign by various exponents of the plain language movement in the English-speaking world to stigmatize shall and to call for its elimination from legal texts: 'Give shall the boot' (Kimble 2000) and 'Shall must go' (Asprey 1992) are two of the more eloquently worded suggestions on the topic. The outcome of this campaign to oust shall is that in the legislative texts drafted by many countries today shall has either disappeared or else its use has been drastically reduced with respect to the 1970s. But there are exceptions: for example, in the European Union the frequency of shall has remained virtually unchanged over the last few decades compared with the situation of national legislation in the UK and Australia, as can be seen in Table 1 based on the data of the corpora compiled for this paper.

Table 1. Frequency of shall per 1,000 words

\begin{tabular}{|l|c|c|c|c|c|}
\hline & 1973 (UK 1970) & 1980 & 1990 & 2000 & 2010 \\
\hline UK & 12.7 & 14.1 & 9.7 & 10.6 & 0.2 \\
\hline Australia & 6.7 & 8.1 & 1.2 & 0.0 & 0.0 \\
\hline EU & 14.7 & 12.7 & 11.3 & 13.6 & 10.0 \\
\hline
\end{tabular}

\footnotetext{
8 'Order for maintenance of party to marriage made by magistrates' court to cease to have effect on remarriage of that party' from the UK Matrimonial Proceedings and Property Act 1970.

${ }^{9}$ Section 3(3)(a) of the UK Imprisonment (Temporary Provisions) Act 1980.

${ }^{10}$ Section 2 of the US Patriot Act 2001, at http://epic.org/privacy/terrorism/hr3162.html (last accessed 13 April 2010).

${ }^{11}$ Adams claims that even if "the corporate bar is addicted to shall, with business contracts exhibiting rampant overuse of the word" (2008: 33), the risks it poses in contract drafting "can be overstated" (2008: 35), because shall conveys a more restricted number of meanings which makes it use unexceptionable.
} 
By taking data at ten-year intervals it is possible to pinpoint, in the case of Australia and the $\mathrm{UK}$, the moment when the policy to do away with, or drastically reduce, the frequency of shall became operative, as is eloquently expressed in Figure 1 below.

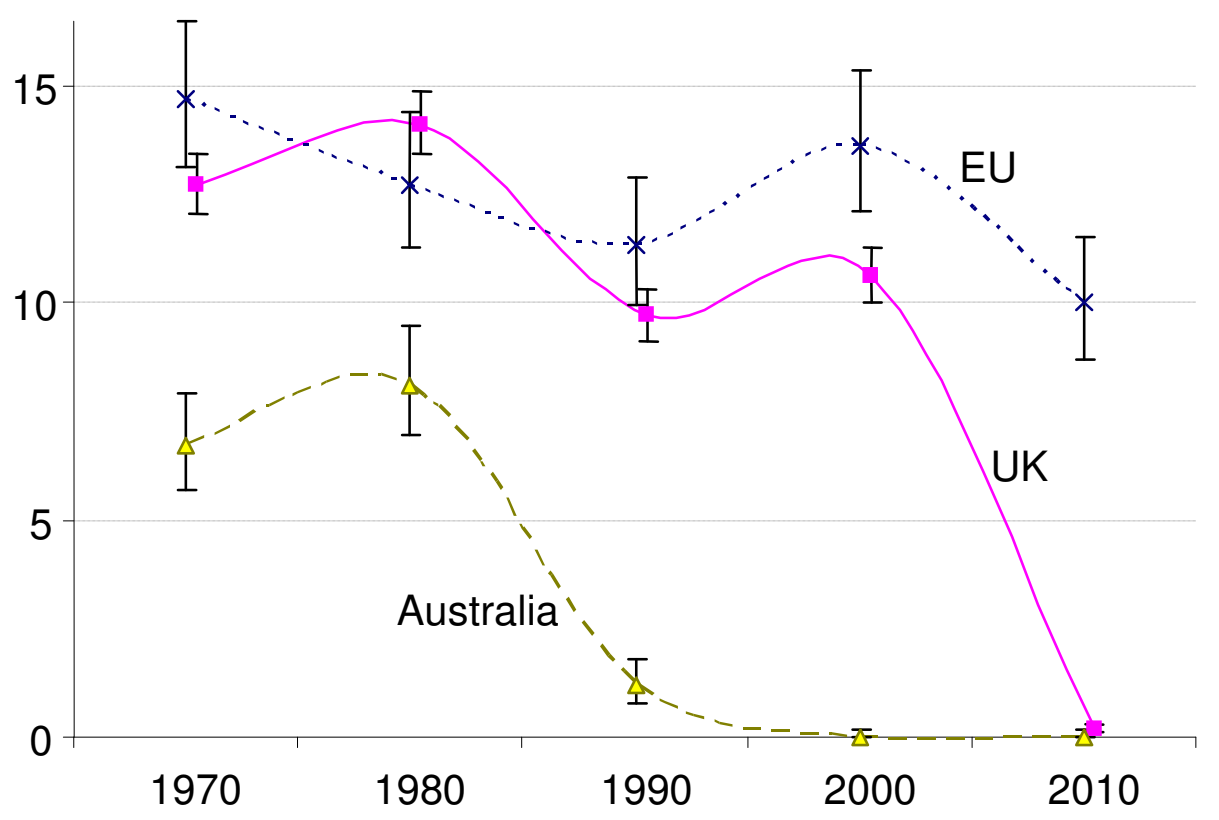

Figure 1. Frequency of shall per thousand words over time for each subcorpus. The 'I'-shaped bars represent 95\% confidence intervals calculated by Wilson's score interval method (see Appendix 1 in Aarts et al. this volume). Notice that the error bars in the upper left portion of the figure overlap.

Australia was the first English-speaking country to implement this change, and the data reveal - as can be seen by comparing the sharp drop from 8.1 per 1,000 words in 1980 to just 1.2 per 1,000 words in 1990 - that this occurred during the 1980s. Michèle Asprey, one of the most influential voices in Australia for modernising legal drafting, confirms (p.c.) that this change occurred during the late 1980s following the recommendations of the Law Reform Commission of Victoria on plain language drafting.

In the UK the decision to oust shall only became operative relatively recently, some time between 2001 and 2010, as can be seen by comparing the figures for 2000 (10.6 per 1,000 words) with those of 2010 ( 0.2 per 1,000 words). It should also be borne in mind that of the few occurrences of shall in 2010 some are simply due to textual amendments, as in (6).

(6) In section 24(1) of the Broadcasting Act 1990 (Channel 4 to be provided by C4C), for "The function of the Corporation shall be to" substitute "The Corporation must". 12

The situation is rather different in the EU which has had two English-speaking Member States - the UK and the Republic of Ireland ${ }^{13}$ - since $1973 .{ }^{14}$ Precisely because the EU is a multilingual institution with (at present) 23 official languages, it is not easy to introduce sweeping stylistic changes in one language without creating potential problems for other languages. Hence the more conservative approach to legislative drafting: we find shall being used with roughly the same frequency throughout the 37-year period taken into consideration, with only a slight dip discernible in the 2010 data. Here is a typical example from a 2010 text.

\footnotetext{
${ }^{12}$ Section 7(5) of the UK Digital Economy Act 2010.

${ }^{13}$ Gaelic only became the Republic of Ireland's first official language in the EU in 2007.

${ }^{14}$ English (together with Maltese) is also one of the official languages of Malta which entered the EU in 2004.
} 


\section{(7) Article 6}

1. The Standing Committee shall regularly submit a report to the Council on its activities.

2. The Council shall keep informed the European Parliament and the national

Parliaments of the proceedings of the Standing Committee.

\section{Article 7}

This Decision shall enter into force on the date of its adoption.

It shall be published in the Official Journal of the European Union. ${ }^{15}$

However, there are also cases where the massive use of shall in EU texts is particularly striking. For example, it is the fifth most commonly used word in the English version of the 2004 European Constitution (Williams and Milizia 2008: 2213), with 1,703 occurrences in a text of 66,647 words. Nevertheless, a debate is under way among English-speaking drafters in Brussels and Strasbourg as to how to reduce the use of shall without doing away with it completely. ${ }^{16}$ Moreover, there is 'official' recognition within the EU that shall is a problem word, as is expressed by the European Commission Directorate-General for Translation (2010: 36).

(8) 6.14 The use of verbs, in particular the modal verb shall, in legislation often gives rise to problems, since such uses are rarely encountered in everyday speech. Consequently, writers may lack a feel for the right construction. The following section is intended to provide guidance. [...]

6.16 For a positive command, use shall: e.g. This form shall be used for all consignments.

Note that this provision expresses an obligation. However, this is not always the case: e.g. This Regulation shall enter into force on ...

Theoretically, must could be used instead of shall in the first case, while will could be used in both cases. However, this is not the practice in EU legislation.

In order to have a clearer idea of how the campaign against shall has affected the distribution of finite verbal constructions in legislative texts in parts of the English-speaking world over the last few decades, I have compared the finite verbal constructions contained in laws passed by the UK and Australian parliaments over a 30-year period, taking texts published respectively in 1980 and in 2010. Each subcorpus was made up of 20,000 words. For purposes of comparison, only finite verbal constructions with 'prescriptive force' were taken into consideration; all other cases were discarded. ${ }^{17}$ For example, in the citation in (9) below, only the first occurrence of the present simple (It $\underline{\text { is }}$ an offence ...) is counted, but not the remaining three cases (... that $\underline{\text { is }}$ false and that $P \underline{\text { knows }}$ or believes to be false):

(9) It is an offence for a person ("P") with an improper intention to have in P's possession or under P's control-

(a) an identity document that is false and that $\mathrm{P}$ knows or believes to be false. ${ }^{18}$

\footnotetext{
${ }^{15}$ EU Council Decision of 25 February 2010 on setting up the Standing Committee on operational cooperation on internal security.

${ }^{16}$ Colin Robertson (p.c.).

${ }^{17}$ The UK 1980 texts contain 446 prescriptive as opposed to 479 non-prescriptive finite verbal constructions, whereas the figures for the 2010 texts are respectively 607 and 626. The Australian 1980 texts contain 446 prescriptive as opposed to 535 non-prescriptive finite verbal constructions, whereas the figures for the 2010 texts are 441 and 741 , respectively.

${ }^{18}$ Section 4(7) of the UK Identity Documents Act 2010.
} 
The reason for this restriction in choice is that non-prescriptive cases of finite verbal constructions which very frequently occur in subordinate clauses - have been virtually unaffected by the "modal revolution" which essentially revolves around deontic shall. In cases where shall has been eliminated, drafters have had to find suitable alternatives. The results reveal some dramatic fluctuations if we compare the situation in 1980 with that of 2010.

Table 2. Frequency of prescriptive finite verbal constructions: UK

\begin{tabular}{|l|l|l|l|l|l|l|}
\hline UK & shall & must & may & present simple & is to / are to & other \\
\hline 1980 & $276(61.9 \%)$ & $2(0.5 \%)$ & $71(15.9 \%)$ & $83(18.6 \%)$ & $6(1.3 \%)$ & $8(1.8 \%)$ \\
\hline 2010 & $0(0.0 \%)^{19}$ & $87(14.3 \%)$ & $92(15.2 \%)$ & $329(54.2 \%)$ & $45(7.4 \%)$ & $54(8.9 \%)$ \\
\hline
\end{tabular}

Table 3. Frequency of prescriptive finite verbal constructions: Australia

\begin{tabular}{|l|l|l|l|l|l|l|}
\hline Australia & shall & must & may & present simple & is to / are to & other \\
\hline 1980 & $162(36.3 \%)$ & $0(0.0 \%)$ & $105(23.5 \%)$ & $163(36.6 \%)$ & $8(1.8 \%)$ & $8(1.8 \%)$ \\
\hline 2010 & $0(0.0 \%)$ & $85(19.3 \%)$ & $81(18.4 \%)$ & $234(53.1 \%)$ & $27(6.1 \%)$ & $14(3.1 \%)$ \\
\hline
\end{tabular}

Figures 2 and 3 illustrate the striking nature of this change over the 30 -year period. Each value is plotted as a proportion of the total and 95\% confidence intervals are calculated by the Wilson method explained in Appendix 1 of Aarts et al. (this volume). All differences between bars are statistically significant (we can tell because the error bars do not overlap), except those for may.

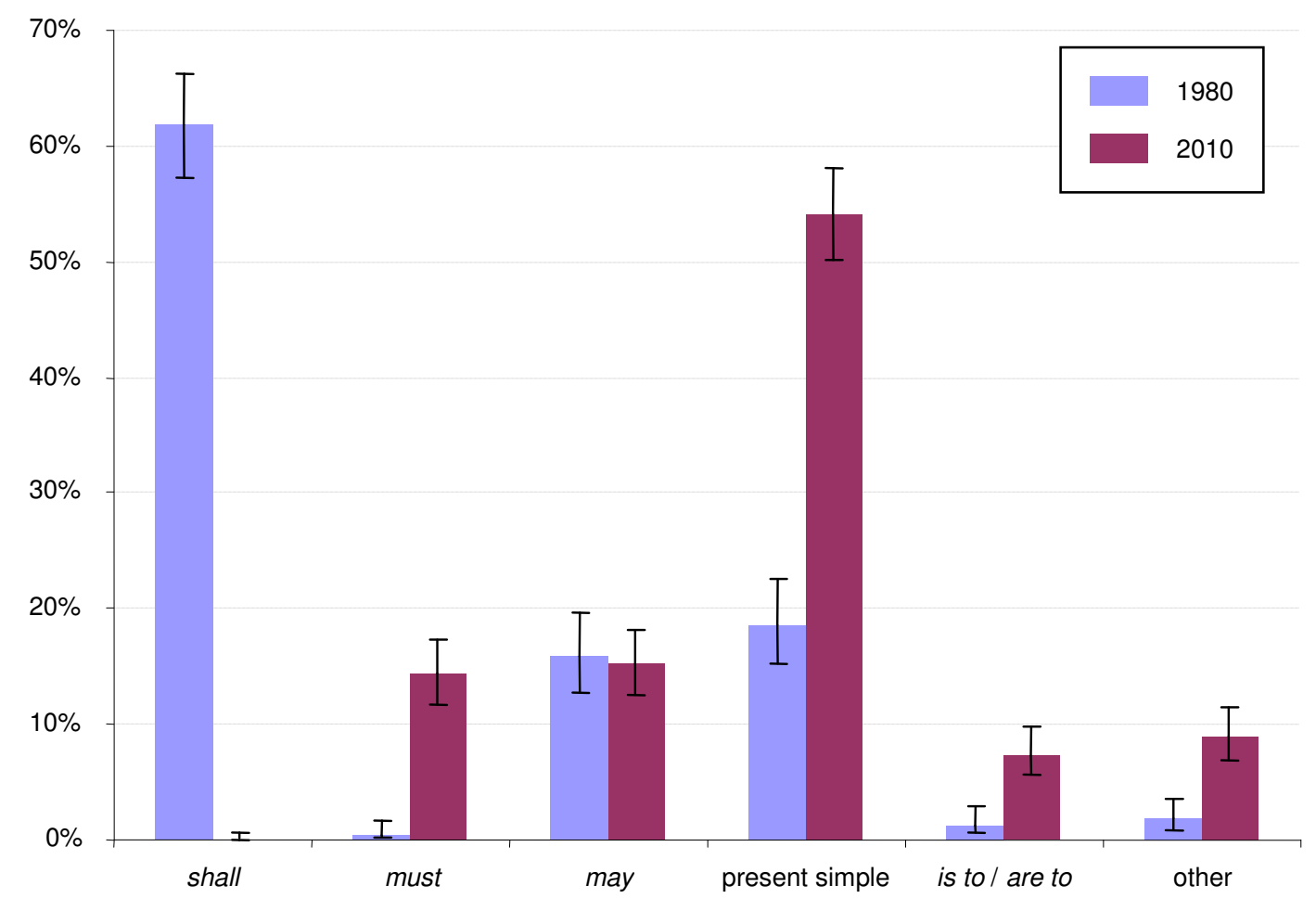

Figure 2. Proportion of prescriptive finite verbal constructions in the UK data for 1980 and 2010 out of the set of forms, with $95 \%$ Wilson error bars.

\footnotetext{
${ }^{19}$ While the overall frequency percentage for shall was 0.2 percent for the UK 2010 texts totalling 100,000 words, there were no occurrences of shall in the 20,000-word sample selected.
} 


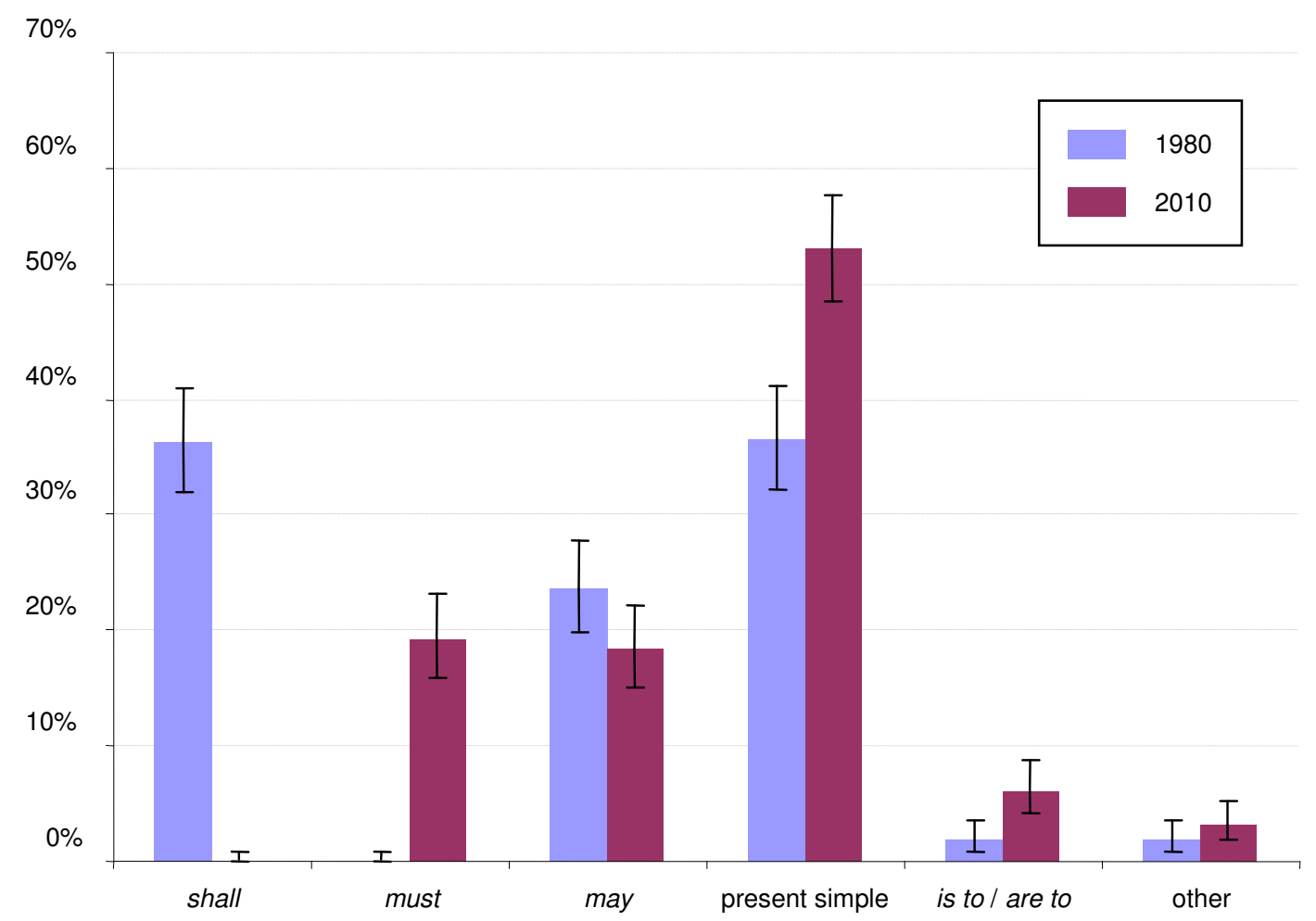

Figure 3. Proportion of prescriptive finite verbal constructions in the Australia data for 1980 and 2010.

Considered as a proportion of finite verbal constructions, for both countries all listed forms with the exception of may change significantly over the period. ${ }^{20}$ The most striking element is, of course, the massive drop in shall which dwindled to nought in both the UK and Australia over the 30-year span. This is particularly noticeable in the UK where shall constituted almost two-thirds of all occurrences in 1980. Even in Australia it made up over a third of all such occurrences in 1980, but we can observe that already by then the present simple was used twice as frequently as it was in the UK.

The second remarkable feature is the predominance in the 2010 texts of the present simple, constituting over 53 percent of all occurrences in both the UK and Australia. Equally dramatic, however, is the rise in the use of must, especially in Australia where it now constitutes almost 20 percent of all occurrences, whereas only 30 years earlier it was totally ignored by drafters. If we look elsewhere, the most striking case involving the replacement of shall by must is undoubtedly that of the English version of the South Africa Constitution. In the Interim version of 1994 we find zero occurrences of must, as against 1,288 occurrences of shall, whereas the definitive version passed only two years later, and in force since 1997, contains 414 occurrences of must, but zero occurrences of shall (Williams 2009: 200). Indeed, must accounts for a massive 28 percent of all finite verbal constructions including indicative tenses (Williams 2005: 190). The main reason for this switch from shall to must is the influence of Canadian lawyer and plain language exponent Phil Knight who joined the Constituent Assembly after the Interim version had been drafted. The following is a typical example of how the 1994 Interim Constitution has been restyled, with the replacement of shall by must, the switch from passive to active voice, the avoidance of syntactic discontinuities, and the elimination of unnecessary words.

(10) Interim version 1994: The detention of a detainee shall, as soon as it is reasonably possible but not later than 10 days after his or her detention, be reviewed by a court

\footnotetext{
${ }^{20}$ Evaluated by the Newcombe-Wilson interval method for comparing proportions: see Appendix 1 in Aarts et al (this volume).
} 
of law, and the court shall order the release of the detainee if it is satisfied that the detention is no longer necessary to restore peace or order

Final version 1997: A court must review the detention as soon as reasonably possible, but no later than 10 days after the date the person was detained, and the court must release the detainee unless it is necessary to continue the detention to restore peace and order. $^{21}$

The cumulative effect of this restyling, particularly the removal of unnecessary words and the way the syntactic discontinuity between shall and be reviewed has been dealt with, is to transform the text from conservative legalese into modern formal prose that a layperson can comprehend without undue difficulty.

The position of may has remained relatively stable over the 30-year period, with only minor fluctuations in frequency in the UK and Australia. It can be used to convey discretion, as in This Act may be cited as the Liquefied Petroleum Gas (Grants) Act $1980,{ }^{22}$ indeed, in the Australian texts analysed it is used purely with this function in its prescriptive sense. In the UK texts it is sometimes used in the negative form (in 17 cases out of 71 in the 1980 texts, and in 5 out of 92 cases in the 2010 texts) to convey prohibition, as in The Treasury may not make more than one interim designation of the same person in relation to the same, or substantially the same, evidence. ${ }^{23}$ It should be pointed out that in legislative texts may can also be used in a non-normative sense when indicating, for example, possibility, as in The Minister must not give directions about the content of any advice that may be given by the Board. ${ }^{24}$ Such cases of may are not taken into consideration here.

An increase in the frequency of the semi-modal is to/are to is also discernible, particularly in the UK data where the 2010 figure is almost six times higher than that of 1980. But also in Australia its frequency has doubled: it is worth noting that Australia's Plain Language Manual (2003: 19) specifically suggests resorting to is to/are to when there is "the need to use a gentler form" than must.

We therefore seem to have a hierarchy of 'normative intensity' with must conveying maximum strength, followed by is to/are to, and then the present simple (Williams 2006: 252-254). Here is an example from the same Australian law of 2010 illustrating all three cases.

(12) The Board must comply with a direction given by the Minister under subsection (1).

(13) A question arising at a meeting is to be determined by a majority of the votes of the members present and voting.

(14) The resignation takes effect on the day it is received by the Minister or, if a later day is specified in the resignation, on that later day. ${ }^{25}$

It is not unfeasible that in the past shall would have been used in all three examples. Equivalent cases using shall with the same verbs (comply with, be determined, and take effect) can all be found in EU texts drafted in 2010.

The Receiving Party shall comply with any such limitations. ${ }^{26}$

\footnotetext{
${ }^{21}$ Respectively, Section 34 (6)(c)(i) of the 1994 Interim South Africa Constitution and Section 37 (6)(e) of the 1997 South Africa Constitution, at www.servat.unibe.ch/icl/sf10000_html (last accessed 27 April 2010).

${ }^{22}$ Australia Liquefied Petroleum Gas (Grants) Act 1980.

${ }^{23}$ Section 6(3) of the UK Terrorist Asset-Freezing etc. Act 2010.

${ }^{24}$ Section 6(3) of Australia Centre for Renewable Energy Act 2010.

${ }^{25}$ Respectively from sections 6, 21 and 16 of Australia Centre for Renewable Energy Act 2010.

${ }^{26}$ Article 4(4) of the EU Agreement between Australia and the European Union on the security of classified information of 13 January 2010.
} 
(16) In order to implement this Agreement, security arrangements shall be mutually determined in writing between the responsible security authorities designated in paragraphs 2, 3 and 4, in order to lay down the standards for the reciprocal protection of Classified Information under this Agreement. ${ }^{27}$ This Decision shall take effect on the day of its notification. ${ }^{28}$

The category designated as 'other' contains an assortment of verbal constructions, including the archaic Be it enacted to be found at the start of enactment clauses, even today in the UK (though no longer in Australia), should, ought to, can, need not and imperatives such as see, insert, omit, or substitute.

In order to investigate in greater detail the redistribution of prescriptive verbal constructions between 1980 and 2010, I have focused on the UK data. Table 2 above highlights the switch from the predominance of shall in 1980 to the predominance of the present simple 30 years later. A second major change that has taken place over the 30-year period in question is a marked decline in the passive, together with a significant rise in the active voice, as is illustrated in Figure 4.

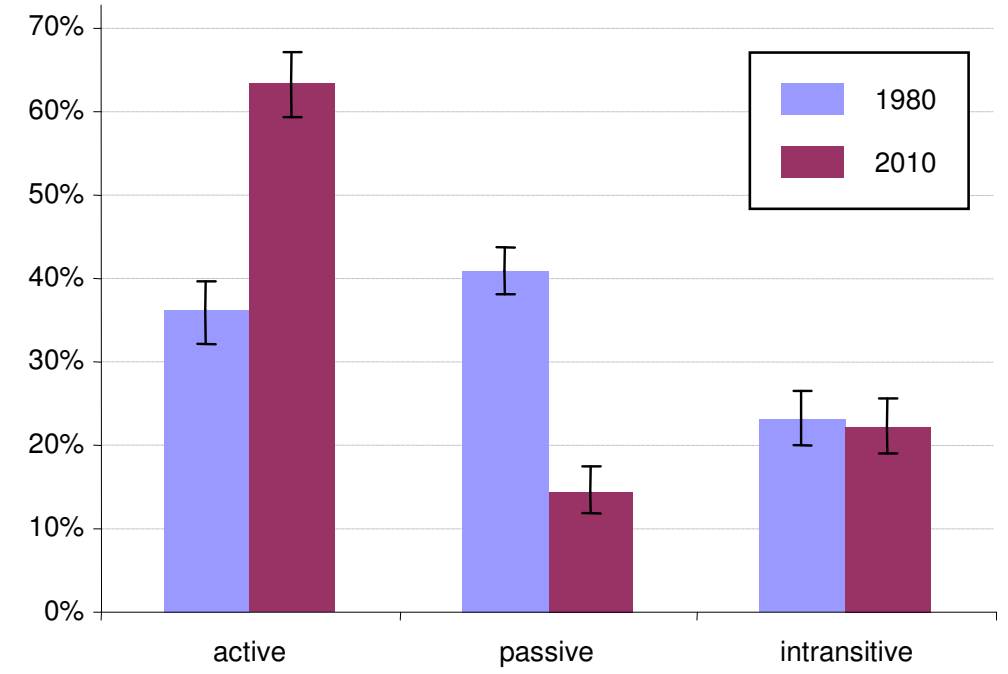

Figure 4. Distribution of actives, passives and intransitives in UK legislative texts in 1980 and 2010

If we discount intransitive verbs, where there is no choice available between active and passive voice (the percentage of intransitives has remained almost unchanged over the 30-year period), we can observe that actives have increased from 46.9 percent in 1980 to 74.0 percent in 2010, while passives have declined from 53.1 percent in 1980 to less than half that total, i.e. 26.0 percent in 2010. These figures are even more striking than those for New South Wales reported in Seoane and Williams (2006: 262) which show a drop in passives from 63.7 percent of all transitive verbs in the early 1970 s to 45.8 percent in texts from 2003-2005, whereas texts taken from US and EU legislation show no decline in the passive over the same period. It should be borne in mind that "Use the active voice rather than the passive voice" (Australia Office of Parliamentary Counsel 2003: 12; United Nations 2007: Chapter VI; Cousineau and Peters 2000) is the advice reiterated in drafting manuals and plain language movements throughout most of the English-speaking world.

\footnotetext{
${ }^{27}$ Article 12(1) of EU Commission Regulation No. 823 of 17 September 2010 implementing Regulation (EC) No. $452 / 2008$ of the European Parliament and of the Council concerning the production and development of statistics on education and lifelong learning, as regards statistics on the participation of adults in lifelong learning.

${ }^{28}$ Article 5 of Council Decision of 10 May 2010 addressed to Greece with a view to reinforcing and deepening fiscal surveillance and giving notice to Greece to take measures for the deficit reduction judged necessary to remedy the situation of excessive deficit (2010/320/EU).
} 
Tables 4 and 5 below provide a more detailed breakdown of how the active-passive ratio has been redistributed between 1980 and 2010 .

Table 4. Active-passive ratios as percentages in UK 1980 texts (excluding intransitives)

\begin{tabular}{|l|l|l|l|l|l|l|}
\hline UK 1980 & shall & must & may & present simple & is to/are to & other \\
\hline active & $59(28.1 \%)$ & $0(0.0 \%)$ & $45(66.2 \%)$ & $49(100 \%)$ & $4(66.7 \%)$ & $2(25.0 \%)$ \\
\hline passive & $151(71.9 \%)$ & $0(0.0 \%)$ & $23(33.8 \%)$ & $0(0.0 \%)$ & $2(33.3 \%)$ & $6(75.0 \%)$ \\
\hline
\end{tabular}

Table 5. Active-passive ratios as percentages in UK 2010 texts (excluding intransitives)

\begin{tabular}{|l|l|l|l|l|l|l|}
\hline UK 2010 & shall & must & may & present simple & is to/are to & other \\
\hline active & 0 & $77(92.8 \%)$ & $62(72.1 \%)$ & $190(93.1 \%)$ & $1(2.3 \%)$ & $44(81.5 \%)$ \\
\hline passive & 0 & $4(7.2 \%)$ & $24(27.9 \%)$ & $14(6.9 \%)$ & $43(97.7 \%)$ & $10(18.5 \%)$ \\
\hline
\end{tabular}

We can analyse these data by considering shall, must etc. as proportions $p$ of the total set of forms and then comparing $p$ values. These proportions are plotted in the graph in Figure 5. As before, readers can identify where differences in proportions are statistically significant by spotting where the 'I'-shaped intervals overlap or not.

We can summarise as follows. In both time periods the present simple is predominantly used in the active voice. Shall tends to be used in the passive in the 1980 data, whereas may tends to be active. In the 2010 data must tends to be used actively, whereas is/to and are/to tend to be used in the passive. Comparing the active and passive over time we can say that out of active cases, shall, may, and is to/are to are falling in use whereas the other forms are increasing. In the 2010 data, where shall has fallen to nought, when drafters do choose to use the passive all other forms increase their share.

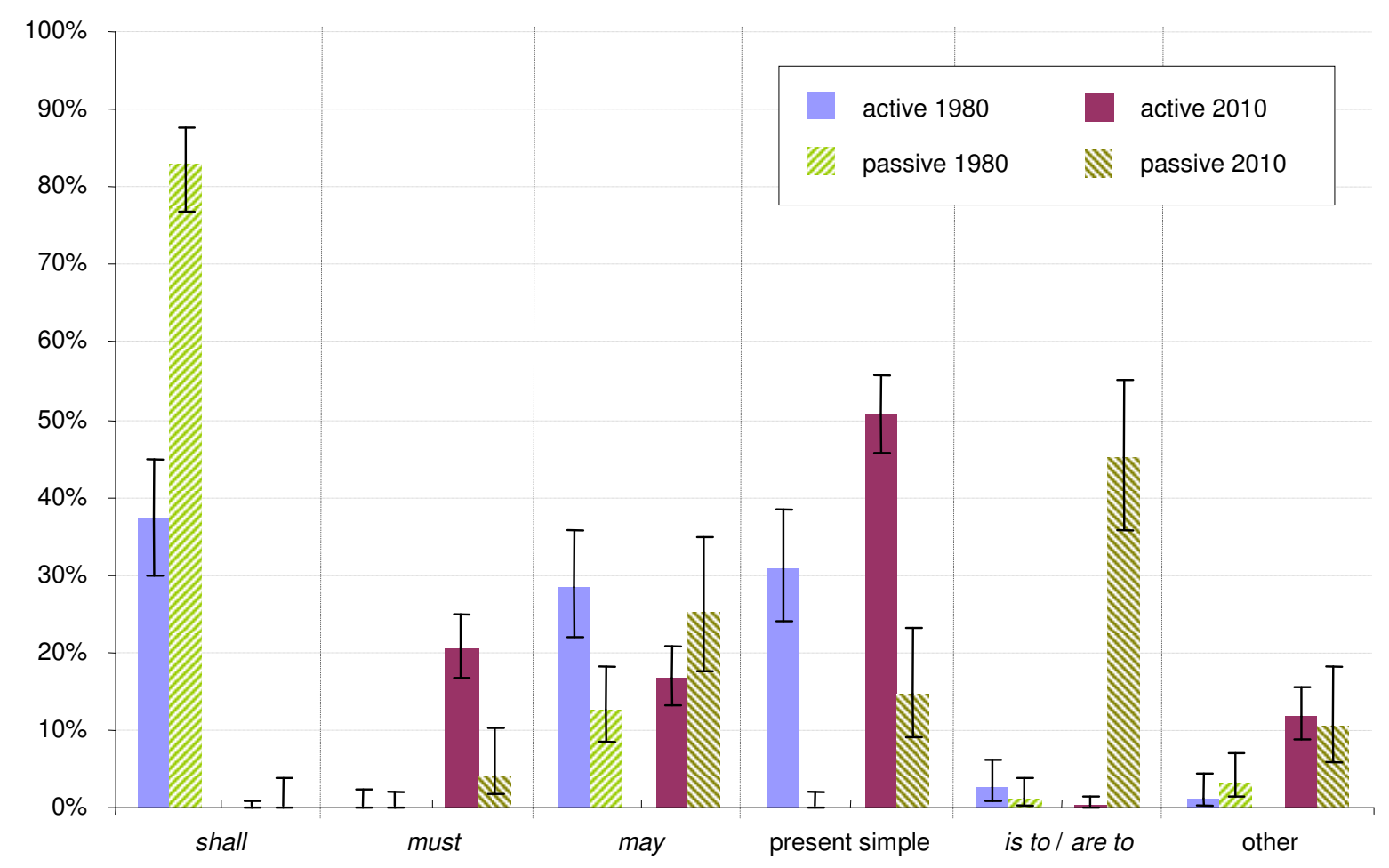

Figure 5. Changing distribution of active and passive verb forms (excluding intransitive forms) in UK legislative texts from 1980 to 2010 . Thus, for example, we can see that may accounts for $12.6 \%$ (23) of passive cases in 1980, rising to $25.3 \%$ (95) by 2010 . As before $95 \%$ confidence intervals are calculated using Wilson's method. 
There are several points worth noting here. First of all, in the 1980 data shall is clearly the main vehicle for conveying passive voice: indeed, 83 percent of all occurrences of the passive are with shall. Here is a typical example.

(18) Sums required by the Treasury for fulfilling any guarantees given under this section shall be charged on and issued out of the Consolidated Fund and any sums received by way of repayment of any sums so issued shall be paid into that Fund. ${ }^{29}$

There is not one instance of the passive with the present simple in the 1980 data. But in spite of the tripling in frequency of the present simple in 2010 with respect to 1980 (see Tables 4 and 5), the percentage of passives is still relatively insignificant at 6.9 percent. Given that the active-passive ratio for may has remained fairly stable over the 30-year period, and that there are relatively few instances of the passive with must in the 2010 data, the other striking feature is that the is to/are to construction - which rose in frequency almost sixfold between 1980 and 2010 - has now become the most commonly used means for conveying passive voice, accounting for 44.3 percent of all occurrences of the passive in the 2010 data. Here is an example.

(1) No ID cards are to be issued by the Secretary of State at any time on or after the day on which this Act is passed.

(2) All ID cards that are valid immediately before that day are to be treated as cancelled by the Secretary of State at the end of the period of one month beginning with that day. ${ }^{30}$

A further point concerns the use of imperatives. In the 1980 data there are no imperatives, whereas in the 2010 data 81.5 percent of all instances of the category labelled 'other' are imperatives (e.g. insert or omit), as in (20).

(b) after sub-paragraph (2)(b) insert-

"(ba) a person equivalent to an insurance company within paragraph (b) whose head office is located in a non-EEA state, when carrying out activities of the kind mentioned in paragraph (b);",

(c) omit sub-paragraph (2)(f), and

(d) after sub-paragraph (2) insert-

“(3)The fact that an institution's head office is located in a non-EEA state does not prevent it from being a credit institution or a financial institution for the purposes of this Schedule." 31

Thirty years earlier, instructions concerning textual amendments were structured differently using shall, as in (21).

For section 8 of the Act of 1971 (borrowing powers) there shall be substituted the following section- "Browsing Power. ${ }^{32}$

Indeed, there are 21 occurrences of there shall be substituted in the 1980 texts. The decision to replace such expressions with imperatives clearly contributes to the marked decline in passives between 1980 and 2010.

\footnotetext{
${ }^{29}$ Section 8(7) of the UK Overseas Development and Co-operation Act 1980.

${ }^{30}$ Section 2(1) of the UK Identity Documents Act 2010.

${ }^{31}$ Section 48(1) of the UK Terrorist Asset-Freezing etc. Act 2010.

${ }^{32}$ Section 14 of the UK Civil Aviation Act 1980.
} 
In the 1980 texts prohibition was conveyed in 80 percent of cases (45 out of 54) by shall not (or variations such as 'No assistance shall be provided ...'); in 2010 the present simple had become the main vehicle for expressing prohibition, constituting 76.3 percent of all cases (42 out of 55). The following examples clearly illustrate this switch from shall to present simple.

$$
\begin{aligned}
& \text { References in the Airports Authority Act } 1975 \text { to aerodromes owned or } \\
& \text { managed by the Authority shall not apply to aerodromes outside Great } \\
& \text { Britain. }{ }^{33}
\end{aligned}
$$

Subsections (8) and (9) do not apply in a case where it appears to the Secretary of State to be desirable to retain the information for the purpose of-

(a) preventing or detecting crime, or

(b) apprehending or prosecuting offenders. ${ }^{34}$

Finally, it is worth pointing out that, if we compare the eight most frequently used verbs in the 1980 and 2010 data, six out of eight appear in both lists - be, apply, mean, have, include and make - with $b e$ as the most frequently used verb in both sets of data, as is illustrated in Table 6.

Table 6. Most frequently used verbs in the UK texts in 1980 and in 2010

\begin{tabular}{|l|l|l|l|l|l|l|l|l|}
\hline 1980 & be & apply & mean & bring & have & substitute & include & make \\
\hline 2010 & be & mean & apply & have & include & insert & make & treat \\
\hline
\end{tabular}

The similarity between the two lists suggests that even if the drafting style has changed in some respects, the verbs most frequently used for laying down provisions in legislative texts have remained relatively stable.

\section{Conclusions}

The data concerning the verb phrase in legislative texts in English suggest that, even in the notoriously conservative world of legal language, the situation has been far from static over the last few decades. Probably the most important feature is constituted by the general shift away from shall - traditionally one of the markers of legal English par excellence - towards the present simple (and, to a lesser extent, towards must), thus bringing prescriptive texts closer in style to those of many continental European countries such as France and Italy where the "normative indicative" (Šarčević 2000: 139) prevails. Paradoxically, it is precisely in the European Union that we still find shall being used with almost the same frequency as it was 30 years ago.

Besides the marked rise in frequency in the present simple, the increased use of must, is/are to and imperatives is also worth highlighting in countries such as Australia and the UK that have decided to do away with - or drastically reduce the use of - shall in legislative texts.

Where changes have taken place in the verb phrase in legislative language in English, these have mainly been the result of pressure exerted by the plain language movement, with some drafting bodies responding to the demands for change faster than others. For example, we have seen from our data that Australia heeded the call about two decades before the UK. Nevertheless, in many of today's legislative texts, e.g. in those of the UK and the United States, it is still possible to find a sprinkling of formulaic expressions that have remained unchanged for centuries, such as $B e$ it enacted. Should such expressions be forced out and replaced by modern equivalents (as Australia has done by adopting the simple formula The Parliament of Australia enacts ...), this will enable

\footnotetext{
${ }^{33}$ Section 24 of the UK Civil Aviation Act 1980.

${ }^{34}$ Section 10 of the UK Identity Documents Act 2010.
} 
laypersons to understand legal texts more easily. However, a sense of history and tradition will inevitably be lost.

\section{References}

Adams, Kenneth A. 2008. A Manual of Style for Contract Drafting. Chicago: American Bar Association.

Asprey, Michèle 1992. Shall must go. Scribes Journal of Legal Writing 3: 79-83.

Australia Office of Parliamentary Counsel 2003. Plain English Manual. At www.opc.gov.au/ about/docs/pem.pdf (last accessed 19 March 2010).

Australian Government Office of Parliamentary Counsel 2009. Plain Language. At www.opc.gov.au/plain (last accessed 25 November 2009).

Bhatia, Vijay K. 1993. Analyzing Genre: Language Use in Professional Settings. London: Longman.

Bhatia, Vijay K. 1994. Cognitive structuring in legislative provisions. In John Gibbons (ed.), Language and the Law. London: Longman: 136-155.

Bhatia, Vijay K., Nicola Langton and Jane Lung 2004. Legal discourse: opportunities and threats for corpus linguistics. In Ulla Connor and Thomas A. Upton (eds.), Discourse in the Professions: Perspectives from Corpus Linguistics. Amsterdam and Philadelphia: John Benjamins: 203-234.

Bowers, Frederick 1989. Linguistic Aspects of Legislative Expression. Vancouver: University of British Columbia Press.

Charrow, Robert and Veda R. Charrow 1979. Making legal language understandable: a psycholinguistic study of jury instructions. Columbia Law Review 79: 1306-1374

Coulthard, Michael and Alison Johnson 2007. An Introduction to Forensic Linguistics: Language in Evidence. London: Routledge.

Cousineau, Carol and Roger Peters 2000. Plain English in Michigan Statues and Rules. Michigan Bar Journal 79 / 1. At: http://tinyurl.com/3g8h5zq (last accessed 1 June 2010).

Crystal, David and Derek Davy 1969. Investigating English Style. London: Longman.

Cutts, Martin 2001. Clarifying Eurolaw. Stockport: The Plain Language Commission Peak Press. Also available at www.clearest.co.uk/files/ClarifyingEurolaw.pdf (last accessed 9 February 2011).

Darmstadter, Howard 2008. Hereof, Thereof and Everywhereof: A Contrarian Guide to Legal Drafting. Chicago: ABA Publishing.

European Commission Directorate-General for Translation 2010. English Style Guide: A handbook for authors and translators in the European Commission. At http://tinyurl.com/68m84ws (last accessed 31 March 2011).

European Parliament, the Council and the Commission 2003. Joint Practical Guide. At http://eurlex.europa.eu/en/techleg/pdf/en.pdf with 2009 updates at http://eur-lex.europa.eu/en/ techleg/pdf/EN-corrections.pdf (last accessed 19 March 2010).

Foley, Richard 2001. Going out of style? Shall in EU legal English. Proceedings of the Corpus Linguistics Conference 2001, University of Lancaster: 185-195.

Gotti, Maurizio 2001. Semantic and pragmatic values of shall and will in Early Modern English Statutes. In Maurizio Gotti and Marina Dossena (eds.), Modality in Specialized Texts. Bern: Peter Lang: 89-111.

Heffer, Chris 2005. The Language of Jury Trial: A Corpus-Aided Analysis of Legal-Lay Discourse. Basingstoke: Palgrave Macmillan.

Kimble, Joseph 2000. A modest wish list for legal writing. Michigan Bar Journal. Also available at www.plainlanguagenetwork.org/kimble/modest.htm (last accessed 13 April 2010).

MacCormick, Neil D. 1978. Legal Reasoning and Legal Theory. Oxford: Oxford University Press. 
Maley, Yon 1994. The language of the law. In John B. Gibbons (ed.), Language and the Law. London: Longman: 11-50.

Mattila, Heikki 2006. Comparative Legal Linguistics. Aldershot: Ashgate Publishers.

Mellinkoff, David 1963. The Language of the Law. Boston and Toronto: Little, Brown and Company.

New Zealand Parliamentary Counsel Office, 2009. Principles of clear drafting. At www.pco.parliament.govt.nz/assets/Uploads/pdf/clear-drafting.pdf (last accessed 19 March 2010).

Office of the Scottish Parliamentary Counsel, 2006. Plain Language and Legislation. At www.scotland.gov.uk/Publications/2006/02/17093804/0 (last accessed 25 November 2009).

Šarčević, Susan 2000. New Approach to Legal Translation. The Hague: Kluwer Law International.

Seoane, Elena and Christopher Williams 2006. Changing the rules: a comparison of recent trends in English scientific discourse and prescriptive legal discourse. In Marina Dossena and Irma Taavitsainen (eds.), Diachronic Perspectives on Domain-specific English. Bern: Peter Lang: 255-276.

Tiersma, Peter M.1999. Legal Language. Chicago: Chicago University Press.

Tiersma, Peter M. 2011. The Nature of Legal Language. At www.languageandlaw.org/ NATURE.HTM (last accessed 29 January 2011).

Trosborg, Anna 1995. Statutes and contracts: an analysis of legal speech acts in the English language of the law. Journal of Pragmatics 23: 31-53.

United Nations, 2007. Writing for the United Nations. New York. At http://69.94.137.26/ editorialcontrol/training/lessons/link_e.htm (last accessed 19 March 2010).

Vázquez, Ignacio 2006. Nominalization in academic lectures: a corpus-based approach. In Carmen Pérez Llantada and Gibson Ferguson (eds), English as a Glocalization Phenomenon. Observations from a Linguistic Microcosm. Valencia: Prensas Universitarias de Valencia: 131-152.

Williams, Christopher 2005. Tradition and Change in Legal English: Verbal Constructions in Prescriptive Texts. Bern: Peter Lang.

Williams, Christopher 2006. Fuzziness in legal English: what shall we do with 'shall'? In Anne Wagner and Sophie Cacciaguidi (eds.), Legal Language and the Search for Clarity. Bern: Peter Lang: 237-263.

Williams, Christopher 2007. Crossovers in legal cultures in Westminster and Edinburgh: some recent changes in the language of the law. ESP Across Cultures 4: 101-18.

Williams, Christopher 2009. Legal English and the 'modal revolution'. In Pierre Busuttil, Raphael Salkie and Johan van der Auwera (eds.), Proceedings of the Second International Conference on Modality in English. Berlin: Mouton de Gruyter: 199-210.

Williams, Christopher 2010. Functional or dysfunctional? The language of business contracts in English. In Rassegna Italiana di Linguistica Applicata 3: 217-227.

Williams, Christopher and Denise Milizia 2008. How (un)readable is the European Constitution? A comparison of the English version and the Italian version. In A. Cannone et al. (eds.), Studi in Onore di Vincenzo Storace. Naples: Editoriale Scientifica: 2209-2227.

Woolever, Kristin R. 2006. Untangling the law: verbal design in legal argument. Journal of Advanced Composition 6. At www.jacweb.org/Archived_volumes/Text_articles/ V6_Woolever.htm (last accessed 9 February 2011).

Wydick, Richard C. 1979. Plain English for Lawyers. Durham, NC: Carolina Academic Press. 